\title{
Use of a modular hip dual-mobility articulation in patients with high risk of dislocation: a relatively small-sized acetabulum in Asian patients may limit its use
}

Ping Keung Chan", Sum Lik Cheung, Kar Hei Lam, Wing Chiu Fung, Vincent Wai Kwan Chan, Amy Cheung, Man Hong Cheung, Henry Fu, Chun Hoi Yan and Kwong Yuen Chiu

\begin{abstract}
Background: Dual-mobility hip component is widely used in Europe and North America, because it effectively reduces hip dislocation in primary and revision total hip arthroplasties. However, reports were limited on the use of dual-mobility articulation in Asian populations.

Purpose: The aim of this retrospective study was to review the use of modular dual-mobility hip articulation in Asian patients with the high risk factor for hip dislocation. We also discussed the potential concern on the use of dual-mobility articulation in Asian patients.
\end{abstract}

Methods: From Jan 2018 to June 2019, 17 patients were included in this study. The mean age of the patients was (73.8 \pm 9.5$)$ years (range: $57-88$ years). The mean size of acetabular cup and modular DM liner were $(49.5 \pm 3.4) \mathrm{mm}$ (range, 46-58 mm) and $(40.7 \pm 3.4) \mathrm{mm}$ (range, 38-48 mm), respectively. The mean follow-up period was (15.8 \pm 3.9) months (range, 11-24 months). The primary outcome was the rate of hip dislocation. The secondary outcomes included the Harris Hip Score. Differences were considered statistically significant at $p<0.05$.

Results: Hip dislocation, loosening, peri-prosthetic fractures, or intra-prosthetic dislocation was not found in the series. The mean preoperative and postoperative Harris Hip Scores were $42.2 \pm 17.2$ (range, 15-80) and $74.7 \pm 13.5$ (range, 52-97), respectively, giving a mean improvement of $32.5 \pm 17.2$ (range, 4-72). The improvement was statistically significant $(p<0.05)$.

Conclusions: In Asian patients with high risk of hip dislocation, the use of modular dual-mobility hip component produces promising outcomes without hip dislocation, but the relatively small-sized acetabulum may limit it widespread application in other populations worldwide.

Trial registration: HKUCTR-2913.

Keywords: Dislocation, Dual mobility, Osteoarthritis, Total hip arthroplasty

\footnotetext{
* Correspondence: cpk464@yahoo.com.hk

Department of Orthopaedics \& Traumatology, Queen Mary Hospital, The

University of Hong Kong, 102 Pok Fu Lam Road, Hong Kong, Hong Kong SAR
}

(c) The Author(s). 2021 Open Access This article is licensed under a Creative Commons Attribution 4.0 International License, which permits use, sharing, adaptation, distribution and reproduction in any medium or format, as long as you give appropriate credit to the original author(s) and the source, provide a link to the Creative Commons licence, and indicate if changes were made. The images or other third party material in this article are included in the article's Creative Commons licence, unless indicated otherwise in a credit line to the material. If material is not included in the article's Creative Commons licence and your intended use is not permitted by statutory regulation or exceeds the permitted use, you will need to obtain permission directly from the copyright holder. To view a copy of this licence, visit http://creativecommons.org/licenses/by/4.0/. 


\section{Background}

Apart from aseptic loosening and infection, another common cause of revision after primary total hip arthroplasty (THA) was instability/dislocation, accounting for $23 \%$ of all THAs, according to an epidemiological study involving 51,345 revision THAs performed in the United States [1].

In 1974, Gilles Bousquet and Andre Rambert first proposed the dual-mobility (DM) concept. The DM concept combines the principles of Charnley's low-friction arthroplasty with the McKee-Farrar concept of increasing femoral head-to-neck ratio to maximize hip stability $[2,3]$. In a DM acetabular cup, there is a mobile polyethylene liner interposed as an additional bearing between the prosthetic head and the acetabular shell [4]. Several meta-analyses and systematic reviews showed the benefit of DM articulation in reducing postoperative dislocation in THA [5-7]. In a recent comparison study, Romagnoli et al. [8] showed the risk ratio of DM bearing group was 0.16 , against a higher risk ratio of the conventional bearing group.

DM articulation was used worldwide for more than 20 years. In the early years, DM articulation was mainly used in the European countries [5]. In 2009, DM design was approved by the United States Food and Drug Administration, and was widely used in North America thereafter due to an increase in availability of the modern DM design. The American Joint Replacement Registry [9] reported an increasing trend of using DM articulation in both primary and revision THAs. The percentages of DM system used in the primary THA increased from 3\% in 2012 to $7 \%$ in 2018, while the DM system employed in revision THAs rose from $11 \%$ to $16 \%$ [9]. However, to the best of our knowledge, there were only five English-language reports discussing the use of DM articulation in Asian patients [10-14].

Hip dislocation is one of the major complications of THA. The reported high risk factors include neurological disabilities (cognitive, motor, or psychiatric disorders), a history of spinal diseases (lumbar stenosis and spinal fusion), etc. [15]. In order to decrease the incidence of hip dislocation, DM articulation was suggested for patients with the risk factors.

This retrospective study aimed to review the use of modular DM hip articulation in Asian patients with the high risk factor of hip dislocation. We also discussed the potential concerns over the use of the implant in Asian populations.

\section{Patients and methods}

This retrospective review was approved by the institutional review board (IRB Reference Number UW 19848). From January 2018 to June 2019, 17 consecutive patients underwent DM THAs in our hospital. The patients were invited to participate in the study after informed consent had been obtained. Our eligibility criteria were high risks of hip dislocation after THA, including abductor deficiencies, a fractured neck of femur, neuromuscular diseases, neurological disabilities (cognitive, motor, or psychiatric disorders), a previous hip surgery (i.e. revision, conversion surgeries), and spinal pathologies (lumbar stenosis, spinal fusion, discectomy, scoliosis, degenerative disc disease) [16-22]. Patients who refused to participate in the study were excluded. All operations were preformed by the same orthopaedic surgeon (PKC), who had a post-fellowship training in arthroplasty for more than 10 years.

\section{Surgical Technique}

The patient was placed in the lateral decubitus position on an arthroplasty specific operating table. Under spinal or general anaesthesia, the operation was performed through the posterior approach. The short external rotators and the posterior capsule were exposed and tagged (to facilitate later repair after the prosthesis had been implanted to enhance hip stability) [23]. The acetabular cup used in this study was Trident PSL Shell (modular DM, Stryker, Mahwah, New Jersey, USA) (Fig. 1). The acetabular cup was implanted with the press-fit technique according to the manufacturer's recommendation.

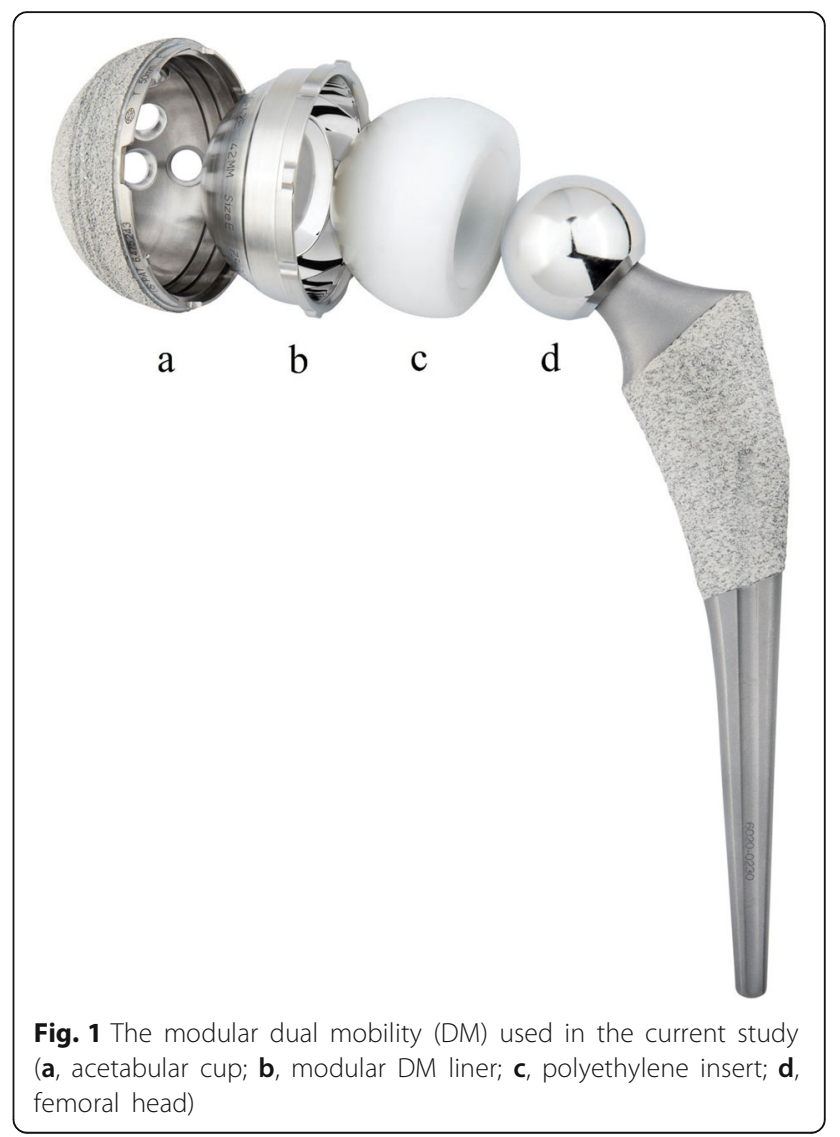


The acetabular component orientation was adjusted according to the Lewinnek safe zone (inclination $30-50^{\circ}$; anteversion 5-25 ) [24]. The cup alignment was aimed at $20^{\circ}$ of anteversion and $40^{\circ}$ of inclination. A cup implanted outside of the Lewinnek safe zone was considered to be in a suboptimal position, which was improved with 2 to 3 supplementary trans-acetabular screws to enhance its mechanical stability. In primary THA, a primary cemented femoral stem (Exeter, Stryker) was used for patients with Dorr Type C stove-pipe canal [25], and a cementless femoral stem (Accolade II or Restoration HA, Stryker) was used for patients with other femoral geometry. In revision THA, the original femoral stem with proper orientation was retained if there was no sign of loosening. Otherwise, the stem was revised with a revision femoral stem (Restoration HA, Stryker). In conversion THA (failed hemi-arthroplasty or failed fixation due to hip fracture), a primary or revision femoral stem was selected. Alternatively, the original femoral stem could be retained only if bone stock was adequate, stability sufficient, and orientation correct. Attention was turned to optimizing the leg length restoration, and intraoperative range of motion, and then stability of the implant were assessed. The posterior capsule and short external rotators were repaired, and the incision was closed in layers.

\section{Postoperative management}

After surgery, the patient stayed in bed, with a hip abduction pillow placed between the two legs. The patient was put on the standardized rehabilitation protocol and trained by the same physiotherapist. Functional training was given by the same occupational therapist. The patient was advised to take the standard hip precautions (avoiding flexion $>90^{\circ}$; adduction $>10^{\circ}$; internal rotation $>10^{\circ}$; crossing of legs; picking up low objects; sitting in low chairs; or prone sleeping position) for 6 weeks. After discharged, the patient was followed up in the outpatient clinic with repeated X-ray examinations after 6 , 3,6 months, and one year.

\section{Outcome evaluation}

Patients' surgical notes, prosthesis details, medical records, and X-rays were reviewed. The primary outcome was the dislocation rate of THA. The secondary outcomes included the Harris Hip Score (HHS). Complications included prosthetic loosening, peri-prosthetic fractures, intra-prosthetic dislocation, among others. The collected data were analyzed with the $t$-test. Differences were considered statistically significant at $p<0.05$.

\section{Results}

A total of 17 patients (male:female $=2: 15$ ) were included in this study, and no patient was excluded. The mean age of the patients was $(73.8 \pm 9.5)$ years (range, 5788 years). There were 9 primary, 6 conversion, and 2 revision THAs. Patients' characteristics and surgical details are shown in Table 1 . The reasons for choosing DM bearings included abductor deficiency $(n=3)$, spinal pathologies $(n=6)$, fractured neck of femur $(n=5)$, previous hip surgeries $(n=8)$, and neurological disabilities $(n=1)$. Six patients had two risk factors of dislocation, and 11 patients had one risk factor. Two typical cases are shown in Figs. 2 and 3.

The mean size of acetabular cup and modular DM liner was $(49.5 \pm 3.4) \mathrm{mm}$ (range, 46-58 $\mathrm{mm}$ ) and $(40.7 \pm 3.4) \mathrm{mm}$ (range, $38-48 \mathrm{~mm})$, respectively. The mean follow-up period lasted $(15.8 \pm 3.9)$ months (range, 11-24 months). Hip dislocation, loosening, periprosthetic fractures, or intra-prosthetic dislocation was not found in our series. No revision THA was required. We excluded two patients with hip fractures, because their preoperative HHSs were not available. For other 15 patients, the mean preoperative and postoperative HHSs were $42.2 \pm 17.2$ (range, 15-80) and 74.7 \pm 13.5 (range, 52-97) respectively, achieving a mean improvement of $32.5 \pm 17.2$ (range, 4-72). The improvement was statistically significant as revealed by paired $t$-test $(p<0.001)$.

\section{Discussion}

A DM implant consists of two articulations. The first articulation is a small inner femoral head fitting the inside of a large hemispherical polyethylene insert. The second articulation is the polyethylene insert articulating with the outer acetabular shell. The inner articulation is responsible for the primary movement of the prosthetic joint, while the outer articulation moves only at the extreme range of movement [26]. DM improves stability and increases range of motion of the hip joint, by means of the increased the headto-neck ratio, a large head size, and a great jump distance [27]. DM articulation is also associated with low dislocation rate and revision rate. Reina et al. [28] reviewed 12 comparison studies published between 2015 and 2018, in which 1132 DM THAs and 1583 conventional THAs were included. With primary THA, the overall dislocation rate of DM implant was $1 \%$, as compared to $7 \%$ of the conventional implants. In revision THA, the overall dislocation rate of DM was $2 \%$, in comparison with $7 \%$ of the conventional implants [28]. The modular dual mobility (Stryker, Mahwah, New Jersey) (Fig. 1) is the only DM designed implant in our region.

\section{DM hip components in Asia}

Mounting evidence has shown the benefits of DM components, but in Asian countries there are only 5 Englishlanguage publications on the use of DM articulation, 
Chan et al. Arthroplasty

(2021) $3: 7$

Page 4 of 10

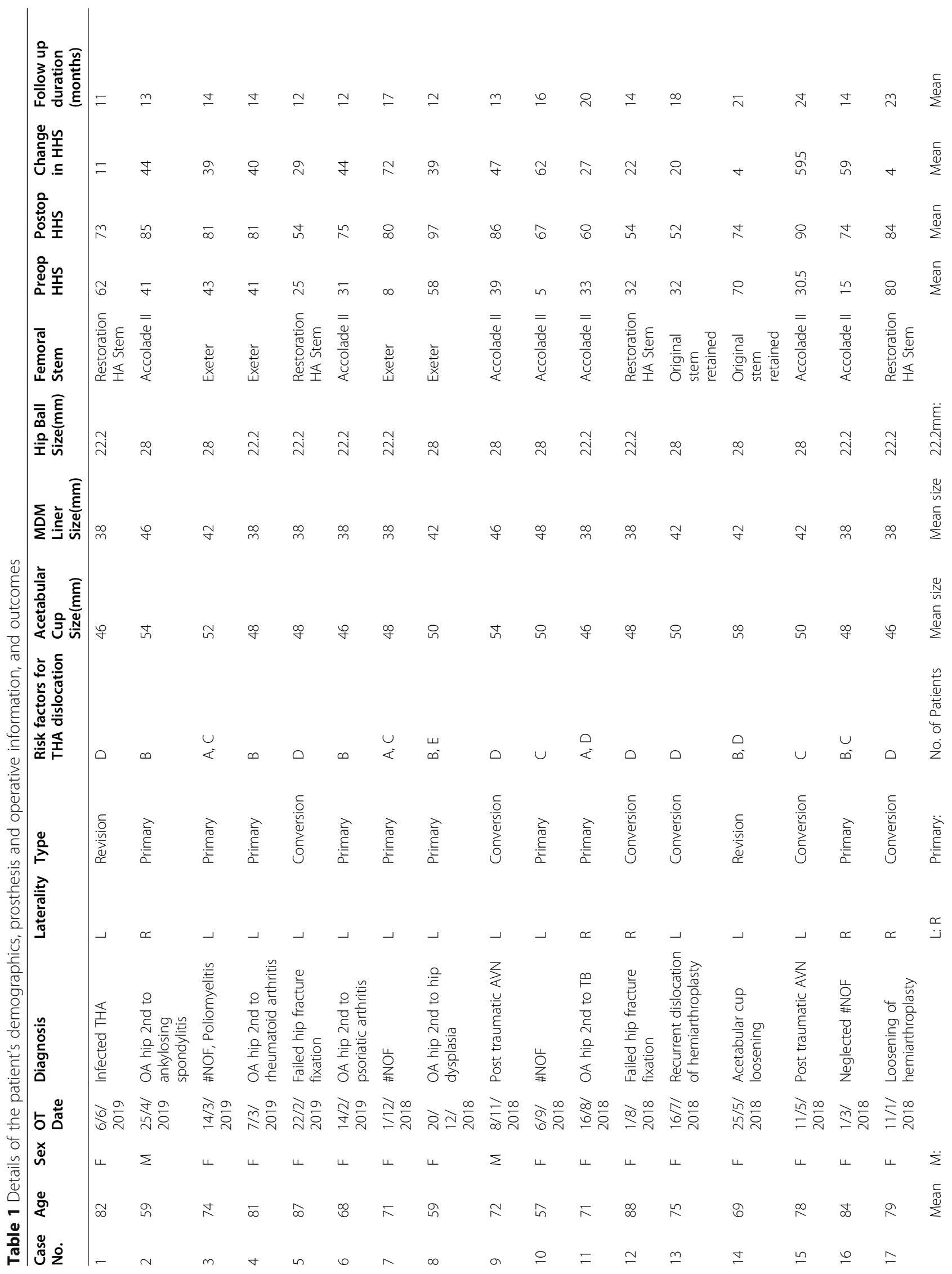




$$
\|
$$




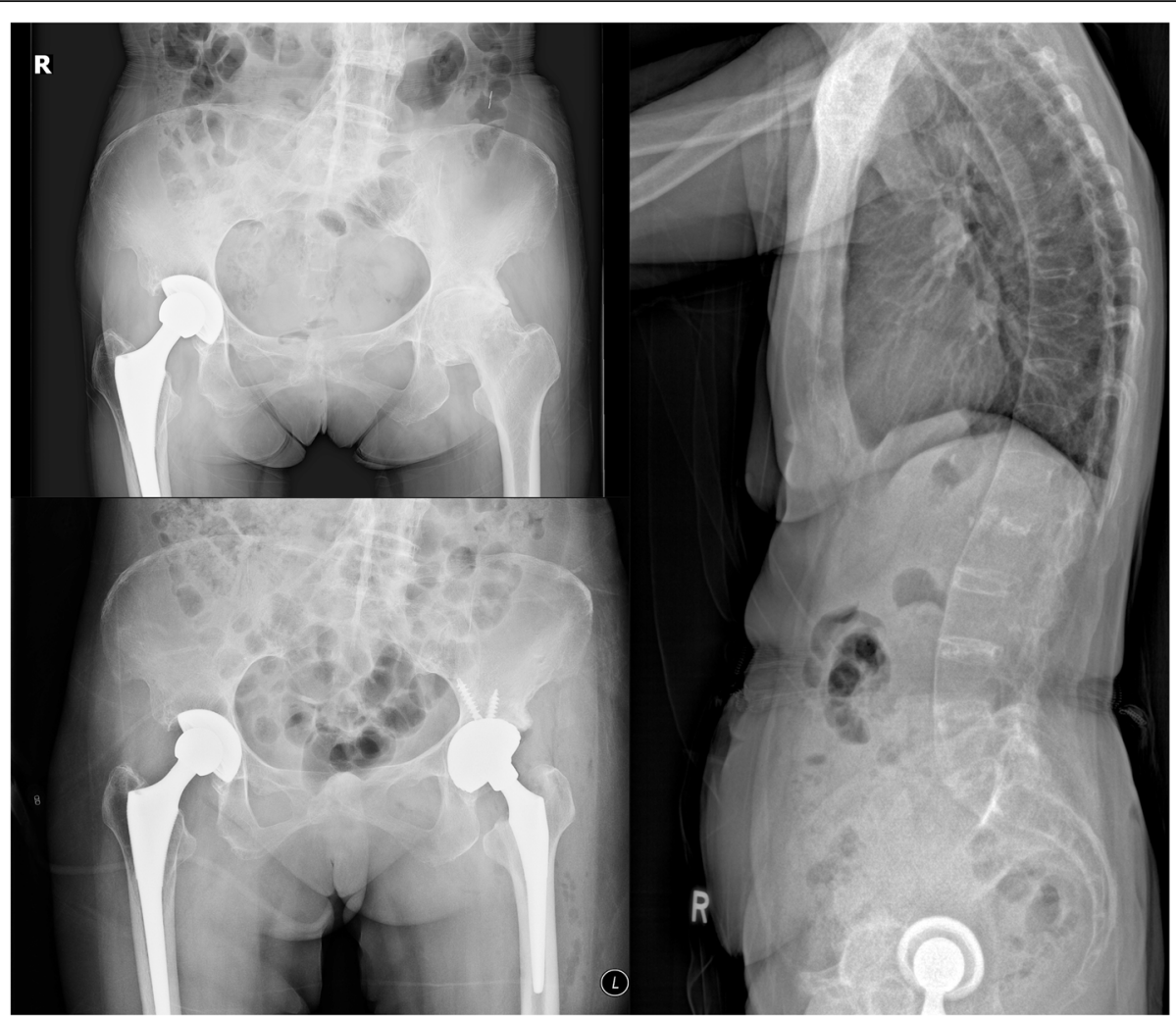

Fig. 2 Case No. 6 in Table 1. a Lateral X-ray showing whole spine spontaneous fusion because of inflammatory arthritis. b Osteoarthritis on the left hip. c DM THA on the left hip with spinopelvic imbalance

including 3 in Japan [10-12] and 2 in Korea [13, 14]. Since 2013, Homma et al. [10] first performed DM THA in 121 patients aged over 70 years, and in patients between 65 and 69 years old who had a high risk of hip dislocation or short life expectancy. They concluded that DM THA is an effective technique in managing patients with femoral neck fracture, and in preventing the high risks of complications [12]. Kim et al. [13] conducted a comparison study between the DM THA and bipolar hemi-arthroplasty for treating displaced femoral neck fractures, and found that the former resulted in a better hip function with lower mortality or dislocation rate.

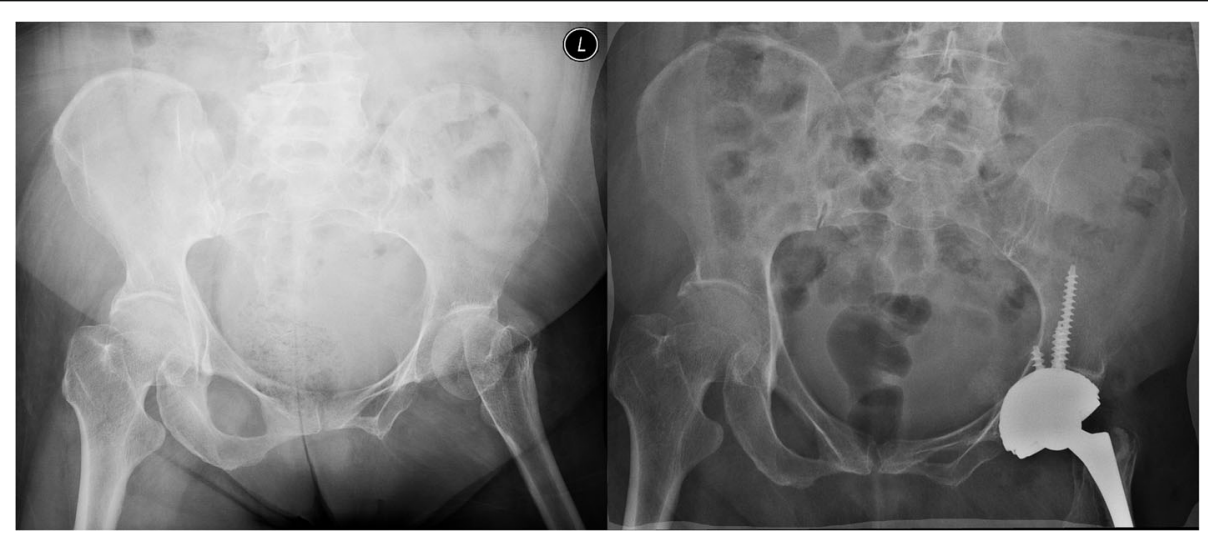

Fig. 3 Case No. 7 in Table 1. a The left hip had a fractured neck of femur with abductor deficiency due to poliomyelitis. b DM total hip arthroplasty on the left hip 


\section{Acetabular cup size in Asian population}

In a dry cadaveric study, Hoaglund and Low compared the sizes of femoral heads in the Caucasian and Hong Kong Chinese populations [29]. Adding an average cartilage thickness of $3 \mathrm{~mm}$ to the femoral head, they found that the femoral head diameter of the Hong Kong Chinese population ( $43 \mathrm{~mm}$ in women; $48 \mathrm{~mm}$ in men) was smaller than that of the Caucasian population $(46 \mathrm{~mm}$ in women; $49 \mathrm{~mm}$ in men). Lee et al. [30] also reviewed 945 Malay patients' femoral heads, including ethnicity of Malay, Chinese, and Indian origins. By measuring the femoral heads taken from the patients who underwent hemi-arthroplasty, they found that the mean diameter of femoral head was $(44.2 \pm 3.0) \mathrm{mm}$ in Malay patients, $(44.4 \pm 3.3) \mathrm{mm}$ in Indian patients, and $(45.2 \pm 3.1) \mathrm{mm}$ in Chinese patients. Therefore, the size of femoral head, and hence the size of acetabulum in Asian populations was relatively smaller than that of the Caucasian populations. Since the smallest MD acetabular cup is $44 \mathrm{~mm}$, it definitely limits its wide application and decreases the potential benefits for Asian populations [31].

\section{Selection of an appropriate modular DM acetabular cup}

Dubin et al. [32] used modular DM articulation in 280 patients in a single hospital in the United States. In their cohort, the mean acetabular cup size was $(53.1 \pm 2.7)$ $\mathrm{mm}$ (range, $44-60 \mathrm{~mm}$ ); and a $50-\mathrm{mm}$ or $52-\mathrm{mm}$ cup combined with a 42-mm modular DM liner was very common, accounting for $59 \%$ of patients in the cohort (Table 2). In our cohort, the mean acetabular cup size was $(49.5 \pm 3.4) \mathrm{mm}$ (range, $46-58 \mathrm{~mm}$ ). There was a statistically significant difference between the above two cohorts $(p<0.001)$. Approximately $53 \%$ of our patients used a $46-\mathrm{mm}$ or $48-\mathrm{mm}$ modular DM cup in combination with a 38-mm modular DM liner. In our hospital, most acetabular cup systems are suitable for the conventional THA, such as Pinnacle (Depuy Synthes), R3 (Smith \& Nephew), and Continuum (Zimmer Biomet). The smallest cup size is $52 \mathrm{~mm}$ and it matches $36-\mathrm{mm}$ femoral head ball. However, in Trident PSL Acetabular System (Stryker), there are smaller cup sizes $(46 \mathrm{~mm}$ or $48 \mathrm{~mm}$ ) that match a 36- $\mathrm{mm}$ femoral head ball if neutral polyethylene liner is used. Therefore, when a $46-\mathrm{mm}$ or 48-mm cup is selected, a 38- $\mathrm{mm}$ mobile polyethylene has only a small increase in diameter compared to a 36$\mathrm{mm}$ femoral head ball used in the conventional THA. Hence, the proposed benefit of DM articulation reduces hip dislocation by increasing primary arc range, and the jump distance was only marginally increased by using a $38-\mathrm{mm}$ femoral head against a $36-\mathrm{mm}$ femoral head used in the conventional THA. Other studies in Asian patients also showed the similar findings with the use of a relatively small cup in DM. Homma et al. $[10,11]$ also reported a median cup size of $50 \mathrm{~mm}$ (range: 46$58 \mathrm{~mm}$ ) and $48 \mathrm{~mm}$ (range, 44-56 $\mathrm{mm}$ ) in two studies. Hwang et al. [14] reported a mean cup diameter of $(50.9 \pm 3.0) \mathrm{mm}$ (range, 44-62 mm).

\section{Selection of an appropriate modular DM femoral Head}

In the modular DM system, a 22.2-mm femoral head well matches a small-sized acetabular cup (Trident PSL cup), including 44-, 46-, and 48-mm cups. For an acetabular cup (Trident PSL cup) $\geq 50 \mathrm{~mm}$, a 28 - $\mathrm{mm}$ femoral head is selected. In our study, $53 \%$ of patients used 22.2- $\mathrm{mm}$ femoral head because of small-sized acetabular cup used whereas only $2 \%$ of patients received $22.2-\mathrm{mm}$ femoral head among patients in Dubin et al's study [32] (Table 3) $(p<0.001)$. Combes et al. [33] argued that intra-prosthetic dislocation was the only risk when a 22 -

Table 2 - Comparison of Acetabular Cup sizes for patients reported in Dublin's study and in current study

\begin{tabular}{lll}
\hline Acetabular cup size $(\mathrm{mm})$ & No. of patients in Dubin's study in United States (\%) & No. of patients in current study (\%) \\
\hline 44 & $1(0.4 \%)$ & $0(0 \%)$ \\
46 & $1(0.4 \%)$ & $4(23.5 \%)$ \\
48 & $1(0.4 \%)$ & $5(29.4 \%)$ \\
50 & $54(19.3 \%)$ & $4(23.5 \%)$ \\
52 & $110(39.3 \%)$ & $1(5.9 \%)$ \\
54 & $49(17.5 \%)$ & $2(11.8 \%)$ \\
56 & $39(13.9 \%)$ & $0(0 \%)$ \\
58 & $17(6.1 \%)$ & $1(5.9 \%)$ \\
60 & $8(2.9 \%)$ & $0(0 \%)$ \\
62 & $0(0 \%)$ & $0(0 \%)$ \\
mean & total $=280$ & total $=17$ \\
median & cup size $=53.1 \mathrm{~mm}$ & cup size $=49.5 \mathrm{~mm}$
\end{tabular}

$p$-value $<0.001$ (Independent samples $t$-test) 
Table 3 Diameter of femoral head used in MDM in Dublin's study and in current study

\begin{tabular}{lrcr}
\hline Head Diameter $(\mathrm{mm})$ & No. of patients in Dubin's study (\%) & No. of patients in current study (\%) & $\begin{array}{l}p \text {-value } \\
\text { (Chi-square test) }\end{array}$ \\
\hline 22.2 & $5(1.8 \%)$ & $9(52.9 \%)$ & $<0.001$ \\
28 & $273(98.2 \%)$ & $8(47.1 \%)$ & \\
\hline
\end{tabular}

$\mathrm{mm}$ head was used. This is of particular relevance to our patient group, because such head was used in 53\% of our patients. Intra-prosthetic dislocation is the complication specific to DM articulation. It refers to a dislocation of polyethylene liner head from the inner femoral head as the consequence of the degeneration of the polyethylene retentive rim. The dislocated polyethylene liner is classically described as the C-shaped bubble displaced outside of the hip joint on X-ray. Upon review of 1960 primary DM THAs which were followed up for an average period of 14 years, Philippot et al. [34] found that the intra-prosthetic dislocation rate was $4 \%$. Intraprosthetic dislocation is one of the main concerns that limited DM usage, especially the early DM design. Levin et al. [35] reported that the incidence dropped to $0.3 \%$ with the use of the modern DM. Therefore, the modern DM is advised for small acetabulum in Asian patients.

\section{Implant materials and design}

With the first-generation DM bearings, the stainless-steel acetabular socket was coated with alumina and the inner surface was polished. The inner femoral head was made of metal, and the mobile layer was made of ultra-high molecular weight polyethylene [36]. The first-generation design was criticized by Blakeney et al. [37] for its undesirable outcomes, i.e., $3 \%$ of implant loosening, $2 \%$ of significant wear, and $5 \%$ of intra-prosthetic dislocation [34]. These complications were mainly the results of the poor cup fixation and premature wear of polyethylene layer, particularly at the retentive rim [37]. Since the early 2000s, there has been a remarkable improvement in terms of implant design and materials used. The modern DM bearings were coated with a bilayer of porous titanium, with or without hydroxyapatite, instead of alumina as the acetabular coating, to optimize bone fixation [38]. As a result, the decreased cup loosening renders the implant comparable to the fixed inserts used in the conventional THA [39]. Moreover, the highly cross-linked polyethylene (HXLPE) used with enhanced polyethylene rim durability and the additional retentive chamber have substantially improved the long-term survivorship of the modern implants $[38,40]$. Together with a more polished and thinner femoral neck [38, 40], the modern design decreases the risk of intra-prosthetic dislocation and achieves a better retention mechanism of the polyethylene head [37]. The superiority of modern designs is supported by laboratory and clinical data. Netter et al. [41] tested the HXLPE DM implant and found it had excellent tolerance for thirdbody particles and good reduction in micro-separation. In 2013, Stryker Orthopaedics compared modern HXLPE DM implants and the first-generation implants, and found that the former had $75 \%$ of reduction in wear [42]. Darrith et al. [40] performed a systematic review involving 54 articles (10,783 primary THAs) in which either firstgeneration or modern DM cups were used. They did not find an intra-prosthetic dislocation in primary THAs performed after 2007.

\section{Stryker Trident acetabular shell}

The Stryker Trident acetabular shell features titanium with grit-blasted hydroxyapatite coating, which has received the approval of the Food and Drug Administration (FDA) in 2003 [43]. The modular DM metal liner, made of cobalt chromium, engages the Trident shell in appropriate orientation of locking tabs and is impacted into the tapered shell [44]. Multiple studies examined the incomplete seating associated with the Trident ceramic metal-backed liner [45-48]. Similar complications due to incomplete seating of the modular DM liner were also reported recently. Padgett et al. [49] reported the incidence of mal-seated modular DM liner was $6 \%$ as shown by postoperative X-rays. In their series, 32 out of 521 Stryker acetabular cups were made on the basis of three different cup designs: Trident I hemispherical cup (8\%), Trident I PSL cup (5\%), and Trident II cup (4\%). The clinical impact of mal-seated liner is still unknown. Theoretically, the risk of micromotion along the malseated interfaces leading to fretting and corrosion remains a concern.

\section{Tips for using modular DM system}

Despite the improvements in modern DM, some tips are worth following for a successful THA. We put the tips into practice in the use the modular DM system, especially, to avoid the incomplete seating of the metal liner. First, excessive under-reaming of acetabulum should be avoided, because the impact caused by press-fitting may lead to in deformation of the metal acetabular shell [4553]. This potentially causes mal-alignment of the cup and liner-locking mechanism, resulting in improper liner seating. The taper of the liner may also be damaged during the insertion, resulting in the failure of the taperlocking mechanism and seating failure. In a cadaveric 
study, Markel et al. [51] tested the press-fit technique using Trident acetabular shells, and found that compression deformation occurred in all their tests, with an average of $0.17 \mathrm{~mm}$ of pinch deformity. Second, the screw head should be completely countersunk into the screw hole in the acetabular cup, and avoid soft tissue interposition between the acetabular cup and modular DM liner. Third, the modular DM liner should be properly seated into the acetabular cup and checked radiologically as needed. Eskildsen et al. [54] reported that the inferomedial portion of the modular DM liner might be mal-seated even if the visible superior portion of modular DM seemed to be well-seated.

\section{Limitations of the study}

The lacks of randomization and a comparison against non-DM bearing are the major limitations of the study. We did not do so because of our small sample size, insufficient statistical power, and various confounding factors that cannot be totally controlled. Longer-term follow-up is required to find out the actual incidence of late dislocation. The cups used in Asian populations are small, which may limit its utilization in Caucasian populations.

\section{Conclusions}

In Asian populations with high risk of hip dislocation, the use of modular DM articulation produces promising outcomes, without causing hip dislocation, but the relatively small-sized acetabulum may limit its extensive application in other populations worldwide.

\section{Abbreviations}

DM: Dual Mobility; THA: Total Hip Arthroplasty; HHS: Harris Hip Score

\section{Acknowledgements \\ We are indebted to Ms. Ka Lee Kelly Li for her assistance in the English editing.}

\section{Authors' contributions}

PK Chan: Conception, Design of the work and drafting of manuscript. SL Cheung: Drafting of manuscript, data acquisition, analysis of data. KH Lam: Data acquisition, analysis of data. WC Fung: Data acquisition, analysis of data. WWK Chan: Drafting of manuscript, conception. A Cheung: Data acquisition, conception. MH Cheung: Data acquisition, analysis of data. H Fu: Data acquisition, analysis of data. CH Yan: Provision of expert advices and revision comments. KY Chiu: Provision of expert advices and revision comments. The author(s) read and approved the final manuscript.

\section{Funding}

The authors received no financial support for the research, authorship and/or publication of this article.

\section{Availability of data and materials}

All data analyzed during this study are included in this article.

\section{Ethics approval and consent to participate}

The need for approval was waived by Institutional Review Board of the University of Hong Kong/ Hospital Authority Hong Kong West Cluster (HKU/ HA HKW IRB).
Consent for publication

Not applicable.

\section{Competing interests}

The authors declare that they have no competing interests.

Received: 25 August 2020 Accepted: 21 December 2020

Published online: 03 May 2021

\section{References}

1. Bozic KJ, Kurtz SM, Lau E, Ong K, Vail TP, Berry DJ. The epidemiology of revision total hip arthroplasty in the United States. J Bone Joint Surg Am. 2009;91(1):128-33. DOl:https://doi.org/10.2106/JBJS.H.00155.

2. Charnley J. The long-term results of low-friction arthroplasty of the hip performed as a primary intervention. J Bone Joint Surg Br. 1972;54(1):61-76. DOl:https://doi.org/10.1302/0301-620X.54B1.61.

3. Bousquet G. Argenson C, Godeneche JL. Cisterne JP, Gazielly DF. Girardin P, Debiesse JL. Recovery after aseptic loosening of cemented total hip arthroplasties with Bousquet's cementless prosthesis. Apropos of 136 cases. Revue de chirurgie orthopedique et reparatrice de l'appareil moteur 1986;72:70.

4. McKee GK, Watson-Farrar J. Replacement of arthritic hips by the McKeeFarrar prosthesis. J Bone Joint Surg Br. 1966;48(2):245-59.

5. Batailler C, Fary C, Verdier R, Aslanian T, Caton J, Lustig S. The evolution of outcomes and indications for the dual-mobility cup: a systematic review. Int Orthop. 2017;41(3):645-59. DOl:https://doi.org/10.1007/s00264-016-3377-y.

6. De Martino I, D'Apolito R, Waddell BS, McLawhorn AS, Sculco PK, Sculco TP. Early intraprosthetic dislocation in dual-mobility implants: a systematic review. Arthroplast today. 2017;3(3):197-202. DOl:https://doi.org/10.1016/j. artd.2016.12.002.

7. Pituckanotai K, Arirachakaran A, Tuchinda H, Putananon C, Nualsalee N, Setrkraising K, Kongtharvonskul J. Risk of revision and dislocation in single, dual mobility and large femoral head total hip arthroplasty: systematic review and network meta-analysis. Eur J Orthop Surg Traumatol. 2018;28(3): 445-55. DOl:https://doi.org/10.1007/s00590-017-2073-y.

8. Romagnoli M, Grassi A, Costa GG, Lazaro LE, Presti ML, Zaffagnini S. The efficacy of dual-mobility cup in preventing dislocation after total hip arthroplasty: a systematic review and meta-analysis of comparative studies. Int Orthop. 2019;43(5):1071-82. DOl:https://doi.org/10.1007/s00264-0184062-0.

9. Registry AJR. Annual Report 2019. American Academy of Orthopaedic Surgeons. 2019. http://connect.ajrr.net/2019-ajrr-annual-report. Accessed 20 Jan 2020.

10. Homma Y, Baba T, Kobayashi H, Desroches A, Ochi H, Ozaki Y, Matsumoto M, Yuasa T, Kaneko K. Benefit and risk in short term after total hip arthroplasty by direct anterior approach combined with dual mobility cup. Eur J Orthop Surg Traumatol. 2016;26(6):619-24. DOl:https://doi.org/10.1007/ s00590-016-1808-5.

11. Homma Y, Baba T, Ozaki Y, Watari T, Kobayashi H, Ochi H, Matsumoto M, Kaneko K. In total hip arthroplasty via the direct anterior approach, a dualmobility cup prevents dislocation as effectively in hip fracture as in osteoarthritis. Int Orthop. 2017;41(3):491-7. DOl:https://doi.org/10.1007/ s00264-016-3332-y.

12. Ochi H, Baba T, Homma Y, Matsumoto M, Watari T, Ozaki Y, Kobayashi H, Kaneko K. Total hip arthroplasty via the direct anterior approach with a dual mobility cup for displaced femoral neck fracture in patients with a high risk of dislocation. Sicot-j. 2017;3. DOl:https://doi.org/10.1051/sicotj/2017048.

13. Kim YT, Yoo JH, Kim MK, Kim S, Hwang J. Dual mobility hip arthroplasty provides better outcomes compared to hemiarthroplasty for displaced femoral neck fractures: a retrospective comparative clinical study. Int Orthop. 2018 Jun; 42(6):1241-6. DOl:https://doi.org/10.1007/s00264-018-3767-4.

14. Hwang JH, Kim SM, Oh KJ, Kim Y. Dislocations after use of dual-mobility cups in cementless primary total hip arthroplasty: prospective multicentre series. Int Orthop. 2018 Apr;42(4):761-7. DOl:https://doi.org/10.1007/s00264017-3660-6.

15. Fessy MH, Putman S, Viste A, Isida R, Ramdane N, Ferreira A, Leglise A, Rubens-Duval B, Bonin N, Bonnomet F, Combes A. What are the risk factors for dislocation in primary total hip arthroplasty? A multicenter case-control study of 128 unstable and 438 stable hips. Orthop Traumatol Surg Res. 2017;103(5):663-8. DOl:https://doi.org/10.1016/j.otsr.2017.05.014. 
16. Wetters NG, Murray TG, Moric M, Sporer SM, Paprosky WG, Della Valle CJ. Risk factors for dislocation after revision total hip arthroplasty. Clin Orthop Relat Res. 2013;471(2):410-6. DOl:https://doi.org/10.1007/s11999-012-2561-7.

17. Gausden EB, Parhar HS, Popper JE, Sculco PK, Rush BN. Risk factors for early dislocation following primary elective total hip arthroplasty. J Arthroplasty. 2018;33(5):1567-71. DOl:https://doi.org/10.1016/j.arth.2017.12.034.

18. Jones CW, De Martino I, D'Apolito R, Nocon AA, Sculco PK, Sculco TP. The use of dual-mobility bearings in patients at high risk of dislocation. Bone Joint J. 2019;101(1_Supple_A):41-5. DOl:https://doi.org/10.1302/0301-620X. 101B1.BJJ-2018-0506.R1.

19. Fessy MH, Putman S, Viste A, Isida R, Ramdane N, Ferreira A, Leglise A, Rubens-Duval B, Bonin N, Bonnomet F, Combes A. What are the risk factors for dislocation in primary total hip arthroplasty? A multicenter case-control study of 128 unstable and 438 stable hips. Clin Orthop Relat Res. 2017; 103(5):663-8. DOl:https://doi.org/10.1016/j.otsr.2017.05.014.

20. Padgett DE, Warashina $H$. The unstable total hip replacement. Clin Orthop Relat Res. 2004;420:72-9.

21. Patel PD, Potts A, Froimson MI. The dislocating hip arthroplasty: prevention and treatment. J Arthroplasty. 2007;22(4):86-90. DOl:https://doi.org/10.1016/ j.arth.2006.12.111.

22. Dagneaux L, Marouby S, Maillot C, Canovas F, Riviere C. Dual mobility device reduces the risk of prosthetic hip instability for patients with degenerated spine: a case-control study. Orthop Traumatol Surg Res. 2019; 105(3):461-6. DOl:https://doi.org/10.1016/j.otsr.2018.12.003.

23. Zhang $D$, Chen L, Peng $K$, Xing F, Wang H, Xiang Z. Effectiveness and safety of the posterior approach with soft tissue repair for primary total hip arthroplasty: a meta-analysis. Orthop Traumatol Surg Res. 2015;101(1):39-44. DOl:https://doi.org/10.1016/j.otsr.2014.10.015

24. Lewinnek GE, Lewis JL, Tarr RI, Compere CL, Zimmerman JR. Dislocations after total hip-replacement arthroplasties. J Bone Joint Surg Am. 1978;60(2): 217-20

25. Dorr LD, Absatz M, Gruen TA, Saberi MT, Doerzbacher JF. Anatomic Porous Replacement hip arthroplasty: first 100 consecutive cases. Semin Arthroplasty. 1990;1(1):77-86.

26. Plummer DR, Haughom BD, Della Valle CJ. Dual mobility in total hip arthroplasty. Orthop Clin North Am. 2014;45(1):1-8. DOl:https://doi.org/10. 1016/j.ocl.2013.08.004.

27. De Martino I, D'Apolito R, Soranoglou VG, Poultsides LA, Sculco PK, Sculco TP. Dislocation following total hip arthroplasty using dual mobility acetabular components: a systematic review. Bone Joint J. 2017;99(1_Supple_A):18-24. DOl:https://doi.org/10.1302/0301-620X.99B5. 38086c.

28. Reina N, Pareek A, Krych AJ, Pagnano MW, Berry DJ, Abdel MP. Dualmobility constructs in primary and revision total hip arthroplasty: a systematic review of comparative studies. J Arthroplasty. 2019:34(3):594-603. DOl:https://doi.org/10.1016/j.arth.2018.11.020

29. Hoaglund FT, Low WD. Anatomy of the femoral neck and head, with comparative data from Caucasians and Hong Kong Chinese. Clin Orthop Relat Res. 1980;152:10-6.

30. Lee CK, Kwan MK, Merican AM, Ng WM, Saw LB, Teh KK, Krishnan M, Ramiah R. Femoral head diameter in the Malaysian population. Singapore Med J. 2014;55(8):436. DOl:https://doi.org/10.11622/smedj.2014103.

31. Beverland DE, O'Neill CK, Rutherford M, Molloy D, Hill JC. Placement of the acetabular component. Bone Joint J. 2016;98(1_Supple_A):37-43. DOl: https://doi.org/10.1302/0301-620X.98B1.36343.

32. Dubin JA, Westrich GH. Anatomic dual mobility compared to modular dual mobility in primary total hip arthroplasty: a matched cohort study. Arthroplast Today. 2019;5(4):516-21. DOl:https://doi.org/10.1016/j.artd.2019. 09.006.

33. Combes A, Migaud H, Girard J, Duhamel A, Fessy MH. Low rate of dislocation of dual-mobility cups in primary total hip arthroplasty. Clin Orthop Relat Res. 2013;471(12):3891-900. DOl:https://doi.org/10.1007/ s11999-013-2929-3

34. Philippot R, Boyer B, Farizon F. Intraprosthetic dislocation: a specific complication of the dual-mobility system. Clin Orthop Relat Res. 2013;471(3): 965-70. DOl:https://doi.org/10.1007/s11999-012-2639-2.

35. Levin JM, Sultan AA, O'Donnell JA, Sodhi N, Khlopas A, Piuzzi NS, Mont MA. Modern dual-mobility cups in revision total hip arthroplasty: a systematic review and meta-analysis. J Arthroplasty. 2018;33(12):3793-800. DOl:https:// doi.org/10.1016/j.arth.2018.08.013.
36. Cuthbert R, Wong J, Mitchell P, Kumar Jaiswal P. Dual mobility in primary total hip arthroplasty: current concepts. EFORT Open Rev. 2019;4(11):640-6. DOl:https://doi.org/10.1302/2058-5241.4.180089.

37. Blakeney WG, Epinette JA, Vendittoli PA. Dual mobility total hip arthroplasty: should everyone get one? EFORT Open Rev. 2019;4(9):541-7. DOl:https://doi. org/10.1302/2058-5241.4.180045.

38. Aslanian T. All dual mobility cups are not the same. Int Orthop. 2017;41(3): 573-81. DOl:https://doi.org/10.1007/s00264-016-3380-3.

39. Epinette JA, Béracassat R, Tracol P, Pagazani G, Vandenbussche E. Are modern dual mobility cups a valuable option in reducing instability after primary hip arthroplasty, even in younger patients? J Arthroplasty. 2014; 29(6):1323-8. DOl:https://doi.org/10.1016/j.arth.2013.12.011.

40. Darrith B, Courtney PM, Della Valle CJ. Outcomes of dual mobility components in total hip arthroplasty: a systematic review of the literature. Bone Joint J. 2018;100(1):11-9. DOl:https://doi.org/10.1302/0301-620X.100B1. BJJ-2017-0462.R1.

41. Netter JD, Hermida JC, Chen PC, Nevelos JE, D'Lima DD. Effect of microseparation and third-body particles on dual-mobility crosslinked hip liner wear. J Arthroplasty. 2014;29(9):1849-53. DOl:https://doi.org/10.1016/j. arth.2014.04.010

42. Loving L, Lee RK, Herrera L, Essner AP, Nevelos JE. Wear performance evaluation of a contemporary dual mobility hip bearing using multiple hip simulator testing conditions. J Arthroplasty. 2013;28(6):1041-6. DOl:https:// doi.org/10.1016/j.arth.2012.09.011.

43. Stryker S, Protocol. Trident Acetabular System. 2004. https://www. strykermeded.com/media/1157/trident-acetabular-system-psl-surgicalprotocol.pdf. Accessed 15 Jan 2020.

44. Stryker. MDMX3 Surgical Technique, Modular Dual Mobility Acetabular System. 2013. https://www.strykermeded.com/media/1286/mdm-x3-surgicaltechnique.pdf. Accessed 20 Jan 2020.

45. Alba JA, Schiffman ED, Scully SP, Parvataneni HK. Incomplete seating of a metal-backed alumina liner in ceramic-on-ceramic total hip arthroplasty. Orthopedics 2010;33 (1). DOl:https://doi.org/10.3928/01477447-20091124-11.

46. Langdown AJ, Pickard RJ, Hobbs CM, Clarke HJ, Dalton DJ, Grover ML. Incomplete seating of the liner with the Trident acetabular system: a cause for concern? J Bone Joint Surg Br. 2007 Mar;8(3):291-5. DOl:https://doi.org/ 10.1302/0301-620X.89B3.18473.

47. Miller AN, Su EP, Bostrom MP, Nestor BJ, Padgett DE. Incidence of ceramic liner malseating in Trident ${ }^{\oplus}$ acetabular shell. Clin Orthop Relat Res. 2009; 467(6):1552-6. DOl:https://doi.org/10.1007/s11999-009-0770-5.

48. Howcroft DW, Qureshi A, Graham NM. Seating of Ceramic Liners in the Uncemented Trident ${ }^{\circledR}$ Acetabular Shell: Is There Really a Problem? Clin Orthop Relat Res. 2009;467(10):2651-5. DOl:https://doi.org/10.1007/s11999009-0974-8.

49. Padgett DE, Romero J, Wach A, Wright TM. INCIDENCE OF LINER MALSEATI NG IN DUAL MOBILITY IMPLANTS. Orthop Proc. 2019:101(Suppl 12):2.

50. Iwai S, Kabata T, Maeda T, Kajino Y, Kuroda K, Fujita K, Tsuchiya H. Using intraoperative radiography to detect incomplete seating of Trident acetabular system ceramic liners. Eur J Orthop Surg Traumatol. 2013;4(1):215. DOl:https://doi.org/10.1007/s12570-012-0150-6.

51. Markel D, Day J, Siskey R, Liepins I, Kurtz S, Ong K. Deformation of metalbacked acetabular components and the impact of liner thickness in a cadaveric model. Int Orthop. 2011;35(8):1131-7. DOl:https://doi.org/10.1007/ s00264-010-1077-6.

52. McAuley JP, Dennis DA, Grostefon J, Hamilton WG. Factors affecting modular acetabular ceramic liner insertion: a biomechanical analysis. Clin Orthop Relat Res. 2012;470(2):402-9. DOl:https://doi.org/10.1007/s11999-0112193-3.

53. Squire M, Griffin WL, Mason JB, Peindl RD, Odum S. Acetabular component deformation with press-fit fixation. J Arthroplasty. 2006;21(6):72-7. DOI: https://doi.org/10.1016/j.arth.2006.04.016.

54. Eskildsen SM, Olsson EC, Del Gaizo DJ. Canted seating of the Stryker Modular Dual Mobility liner within a Trident hemispherical acetabular shell. Arthroplast Today. 2016;2(1):19-22. DOl:https://doi.org/10.1016/j.artd.2015.05.003.

\section{Publisher's Note}

Springer Nature remains neutral with regard to jurisdictional claims in published maps and institutional affiliations. 